\title{
Quality of life among older adults resident in long-stay care facilities
}

\author{
Luciano Magalhães Vitorino² \\ Lisiane Manganelli Girardi Paskulin ${ }^{3}$ \\ Lucila Amaral Carneiro Vianna ${ }^{4}$
}

Objectives: to evaluate the older adults' perceptions of their quality of life (QoL) in two long-stay care facilities in Pouso Alegre and Santa Rita in Sapucaí, in the State of Minas Gerais, Brazil, and to identify the sociodemographic and health variables which interfere in this perception. Method: a cross-sectional epidemiological study of 77 older adults resident in institutions. The instruments used were: personal characterization; WHOQOL-bref and WHOQOL OLD. Result: the highest average obtained in the instruments was: the "Social Relationships" domain in the WHOQOL-bref (68\%) and the "Sensory abilities" aspect in the WHOQOL-OLD (73.7\%). The variables age, sex, physical activity and level of schooling have a significant correlation with the WHOQOL-bref and the variables sex and leisure have the same with the WHOQOL OLD. Conclusion: older adults who are younger, with higher levels of schooling and who undertake physical and leisure activity have, on average, better perceptions of their QoL. The older adults' QoL in this study had higher rates than that reported in the literature and was similar to that in the community. The results suggest the need to train those involved with older adults in institutions so that they may develop strategies which promote the adaptation, adjustment and maintenance of QoL.

Descriptors: Quality of Life ; Aging; Aged ; Homes for the Aged.

\footnotetext{
Paper extracted from Master's Thesis "Qualidade de vida e coping religioso/espiritual de idosos institucionalizados", presented to Escola Paulista de Enfermagem, Universidade Federal de São Paulo, Brazil.

2 Doctoral student, Escola Paulista de Enfermagem, Universidade Federal de São Paulo, Brazil.

${ }^{3} \mathrm{PhD}$, Adjunct Professor, Escola de Enfermagem, Universidade Federal do Rio Grande do Sul, Brazil.

${ }^{4}$ PhD, Full Professor, Escola Paulista de Enfermagem, Universidade Federal de São Paulo, Brazil.
} 


\title{
Qualidade de vida de idosos em instituição de longa permanência
}

Objetivos: avaliar a percepção da qualidade de vida (QV) dos idosos de duas instituições de longa permanência de Pouso Alegre e Santa Rita do Sapucaí, MG, Brasil, e identificar as variáveis sociodemográficas e de saúde que interferem nessa percepção. Método: trata-se de estudo epidemiológico, transversal, com 77 idosos institucionalizados. Os instrumentos utilizados foram: caracterização pessoal; WHOQOL-bref e WHOQOL-OLD. Resultados: a maior média obtida nos instrumentos foi: WHOQOL-bref domínio "relações sociais" (68\%) e WHQOLOLD faceta "funcionamento do sensório" (73,7\%). As variáveis idade, sexo, atividade física e escolaridade apresentaram correlação significante com WHOQOL-bref e as variáveis sexo e lazer com o WHOQOL-OLD. Conclusão: os idosos mais jovens, com maior escolaridade, que realizavam atividade física e de lazer, apresentaram, em média, melhor percepção na QV. A QV dos idosos deste estudo apresentou maiores índices que os relatados na literatura e foram semelhantes aos da comunidade. Os resultados sugerem a necessidade de se capacitar os envolvidos com os idosos institucionalizados para que desenvolvam estratégias que favoreçam a adaptação, ajustamento e manutenção da QV.

Descritores: Qualidade de Vida; Envelhecimento; Idoso; Instituição de Longa Permanência para Idosos.

\section{Calidad de vida de mayores en institución de larga permanencia}

\begin{abstract}
Objetivos: evaluar la percepción de la calidad de vida de los mayores de dos instituciones de larga permanencia de Pouso Alegre y Santa Rita do Sapucaí, MG; Brasil e identificar los variables sociodemográficos y de salud que interfieren en esta percepción. Método: se trata de un estudio epidemiológico transversal con 77 mayores institucionalizados. Los instrumentos utilizados fueron: caracterización personal; WHOQOL-bref y WHOQOL OLD. Resultados: la mayor media lograda en los instrumentos fue: WHOQOL-bref en el dominio "relaciones sociales" (68\%) y WHQOL-OLD en la faceta "funcionamiento sensorial" $(73,7 \%)$. Los variables edad, sexo, actividad física y escolaridad presentaron correlación significante con WHOQOLbref y las variables sexo y ocio con el WHOQOL OLD. Conclusión: los mayores más jóvenes con mayor escolaridad que realizan actividad física y de ocio presentaron en media mejor percepción en la CV. La CV de los mayores de este estudio presentó mayores índices que los relatados en la literatura y fueron semejantes a los de la comunidad. Los resultados sugieren la necesidad de capacitar los envueltos con los mayores institucionalizados para que desarrollen estrategias que favorezcan la adaptación, ajustamiento y mantenimiento de la CV.
\end{abstract}

Descriptores: Calidad de Vida; Envejecimiento; Anciano; Hogares para Ancianos.

\section{Introduction}

With the epidemiological transition, the rate of institutionalization of older adults has increased in various countries, and this process has occurred in Brazil in a similar way, although it is restricted to the care network for this age group ${ }^{(1)}$.

These changes in the population pyramid have been accompanied by increases in the occurrence of morbidity and disabilities. Even though Brazilian laws assure greater rights for the older adult in his or her family and community, many depend on care in longstay care facilities (LSCF), due to cultural factors, fragility in family arrangements and availability of alternative services ${ }^{(1-2)}$. In 2009, the Brazilian Institute for Geography and Statistics (IBGE) stated that there were approximately 84 thousand Brazilian older adults distributed in 2,072 LSCF in Brazilian territory, with 708 such institutions in the State of Minas Gerais ${ }^{(3-4)}$.

It is this context that justifies this research, as care outside the family ambit for older adults is the responsibility of the LSCF, which becomes an alternative, in some cases voluntary and expected, and must ensure these older adults' quality of life ${ }^{(5)}$. 
The World Health Organization Quality of Life Assessment group defined QoL as the individual's perceptions in the context of their culture and value systems, and their personal goals, standards and concerns $^{(6)}$. The World Health Organization (WHO) developed the WHOQOL-100 instrument for evaluating QoL, with the collaboration of 15 centers in different countries, and with a cross-cultural perspective ${ }^{(7)}$. Next, the WHOQOL-OLD module was also developed which, based on the WHOCOL-100 instrument, and following the same methodological approach, provides an evaluation specifically for older adults(8).

However, QoL has been one of older adults' necessities, as it may be described in terms of functional capacity, independence and capacity to involve oneself in activities of living. One of the principal objectives in research with this age range is to permit older adults to maintain their active contribution to society ${ }^{(9)}$. The institutionalization of older adults is the result of social necessities and this tendency has called the attention of the population in general, and caused some segments of society to concern themselves with the conditions in which this populational segment's QoL is found(10).

The increase in the number of Brazilian older adults in LSCF is evident. This population is tending to grow, due to various factors which include longevity, fragility, the development of chronic degenerative illnesses, impairment of autonomy and weak family structures, which may compromise QoL. QoL is directly associated with the individual and collective attention and care which older adults in institutions receive. One may observe, however, that there is limited scientific production on this construct, without the appropriate exploration concerning people in LSCF.

This study used generic and specific instruments for evaluating QoL. Studies which used both instruments were not found in the Brazilian setting. This was the case only in Spain, among the older adults in both the community and institutions in 2011(11). Apart from anything else, evaluation of the QoL construct in older adults in LSCF can help in the definition of local health policies, for better adaptation and experiences in this phase of life outside the family ambit.

Thus, the present study's objectives were: to evaluate the older adults' perception of QoL, in two LSCF, by means of the generic WHOQOL-bref instrument and the WHOQOL-OLD module and identify which sociodemographic and health factors interfere in these perceptions.

\section{Method}

This is an epidemiological and analytical study with cross-sectional design and a non-probabilistic sample. The study was undertaken in two LSCF, one with 53 residents in the city of Pouso Alegre, and another with 95 older adults in Santa Rita do Sapucaí, totaling 148 older adults; both cities are located in the extreme south of the State of Minas Gerais.

Sample size was calculated based on a stratified random sample, considering a Confidence Interval of $97 \%$. The total sample calculated was of 77 older adults, 41 of whom in Santa Rita do Sapucaí and 35 in Pouso Alegre, with a maximum sample error of $3 \%$. The samples were calculated by strata, and segmented by city. The inclusion criteria were: to be aged 60 or over and reside in one of the LSCF investigated.

The following instruments were used: a) Sociodemographic and health characterization of with closed questions; b) WHOQOL-bref generic instrument for QoL evaluation, with 26 questions, of which two are general and the rest represent each one of the 24 facets which comprise the original instrument. It is made up of four domains: Physical, Psychological, Social relationships and Environment, and the higher the score, the better the QoL, although there is no cutoff point for its classification(12); and c) WHOQOL OLD: the evaluation module of QoL for older adults, with 24 items divided into 6 facets: "Sensory abilities" (SA); "Autonomy" (AUT); "Past, present and future activities" (PPFA); "Social participation" (SP); "Death and dying" (DAD) and "Intimacy" (INT). Each one of the facets has four items. For all the facets, the score of the possible values can vary between 4 and 20 , assuming that all the items were responded to ${ }^{(12)}$.

The generic instrument WHOQOL-bref and the specific instrument WHOQOL-OLS were used in tandem, according to the instructions from the WHOQOL group ${ }^{(12)}$. The instruments' results were transformed into scales from zero to $100 \%$.

Data collection took place in June and July 2010. Prior to the data collection in the LSCF, the research's aims were clarified and the terms of Free and Informed Consent were signed.

The database was managed by one technician and checked by another two, so as to minimize inputting errors during use of the Statistical Package for the Social Sciences (SPSS) software, version 15.0, indicated by the WHOQOL group's researchers ${ }^{(12)}$. 
Analysis was undertaken of the possible associations between the QoL scores from the generic instrument, plus that specific to older adults, and the variables: age, sex, age group, having children, level of schooling, self-assessment of health state, comparison of health state in relation to the previous year, comparison with other people the same age, and leisure activities. Descriptive statistics and inferential statistics were used. Analysis of variance (ANOVA) was used for the analysis of quantitative variables for continuous data possessing three or more categories, the Dunnett or Bonferrori tests for variables with multiple comparisons and the Student t-test for continuous variables in line with parametric assumptions with a level of significance of $5 \%$ ( $p$ $<0.05$ ).

The project was approved by the Ethics and Research Committee of the Federal University of São Paulo (Unifesp), under protocol number 0443/10 and by the Research Ethics Committee of the University of Vale do Sapucaí de Pouso Alegre, Minas Gerais, under protocol no 1289/10.

\section{Results}

The profile of the older adults in the LSCF contained the following: the average age was 76.6 years $(S D \pm 9.5)$, with a maximum extension of 103 years; the older adults' average number of children was 1.9 (DP \pm 3.1 ), and the average length of residence in the LSCF was 9.3 years $(S D \pm 10.6)$ with a maximum extension of 42 years. There was a balance between the sexes: $50.6 \%$ were female; $67.6 \%$ were over 70 years of age; half of the older adults had children (50.6\%); in regards to level of schooling, $81.6 \%$ stated that they had either not attended school, or had not finished their primary education. In relation to marital status, the majority was single (51.9\%). The majority of the older adults (72.7\%) evaluated their health state as good to excellent. Regarding the perception of their health compared to the previous year, $44.2 \%$ stated that it had not changed. Comparing their health state with that of the other older adults, $75 \%$ said that it was better or much better. Of the older adults questioned, $51.9 \%$ did not practice any leisure activities in the LSCF.

Table 1 - The older adults' scores for the domains of the WHOQOL-bref in the LSCF of Pouso Alegre and Santa Rita do Sapucaí, Minas Gerais, Brazil, $2011(n=77)$

\begin{tabular}{|c|c|c|c|}
\hline WHOQOL-bref by domains & Average (士SD) & Median & Amplitude \\
\hline Physical & $63.2( \pm 22.3)$ & 64.3 & $14.3-100$ \\
\hline Psychological & $64.9( \pm 17.6)$ & 66.7 & $29.2-95.8$ \\
\hline Social relationships & $68( \pm 20.2)$ & 66.7 & $0-100$ \\
\hline Environment & $66( \pm 25)$ & 65.6 & $25-100$ \\
\hline
\end{tabular}

Table 2 - The older adults' scores for the facets of the WHOQOL OLD in the LSCF of Pouso Alegre and Santa Rita do Sapucaí, Minas Gerais, Brazil, 2011 ( $n=77$ )

\begin{tabular}{|c|c|c|c|}
\hline WHOQOL OLD by facets & Average ( $\pm S D)$ & Median & Amplitude \\
\hline Sensory abilities & $73.7( \pm 22.7)$ & 75 & $18.8-100$ \\
\hline Autonomy & $56.9( \pm 22)$ & 56.3 & $12.5-93.8$ \\
\hline Past, present and future activities & $60.2( \pm 19.2)$ & 56.3 & $18.8-100$ \\
\hline Social participation & $58.6( \pm 21.5)$ & 62.5 & $12.5-93.8$ \\
\hline Death and Dying & $71.8( \pm 23)$ & 75 & $12.5-100$ \\
\hline Intimacy & $58.4( \pm 21.7)$ & 62.5 & $0-93.8$ \\
\hline
\end{tabular}


Table 3 - Distribution of the averages for the variables Sex and Physical Activity of the domains of the WHOQOL-bref of the older adults in the LSCF of Pouso Alegre and Santa Rita do Sapucaí, Minas Gerais, Brazil, 2011 ( $n=77)$

\begin{tabular}{|c|c|c|c|c|}
\hline \multirow{2}{*}{$\begin{array}{c}\text { WHOQOL-bref } \\
\text { Domains }\end{array}$} & \multicolumn{4}{|c|}{ Sociodemographic variables } \\
\hline & \multicolumn{2}{|c|}{ Sex } & \multicolumn{2}{|c|}{ Physical Activity } \\
\hline \multirow[t]{3}{*}{ Physical } & Male & 71.01( \pm 20.9$)$ & Yes & $73.41( \pm 19.35)$ \\
\hline & Female & $55.59( \pm 21.72)$ & No & $53.75( \pm 20.78)$ \\
\hline & $p$ & $0.002^{*}$ & $p$ & $<0.001^{*}$ \\
\hline \multirow[t]{3}{*}{ Psychological } & Male & $69.63( \pm 16.09)$ & Yes & $73.31( \pm 13.97)$ \\
\hline & Female & $60.36( \pm 18.08)$ & No & $57.19( \pm 17.27)$ \\
\hline & $\mathrm{p}$ & $0.020^{*}$ & $\mathrm{p}$ & $<0.001^{*}$ \\
\hline \multirow[t]{3}{*}{ Social Relationships } & Male & $73.68( \pm 18.23)$ & Yes & $69.37( \pm 22.31)$ \\
\hline & Female & $62.39( \pm 20.37)$ & No & $66.67( \pm 18.2)$ \\
\hline & $\mathrm{p}$ & $0.013^{*}$ & $p$ & 0.561 \\
\hline \multirow[t]{3}{*}{ Environment } & Male & $71.46( \pm 15.3)$ & Yes & $72.21( \pm 15.13)$ \\
\hline & Female & $60.74( \pm 13.71)$ & No & $60.31( \pm 13.45)$ \\
\hline & $\mathrm{p}$ & $0.002^{*}$ & $\mathrm{p}$ & $<0.001^{*}$ \\
\hline
\end{tabular}

* Significance $p<0.05$

Table 4 - Distribution of the averages of the variables sex and leisure activities of the facets WHOQOL OLD of the older adults in the LSCF of Pouso Alegre and Santa Rita do Sapucaí, Minas Gerais, Brazil, $2011(n=77)$

\begin{tabular}{|c|c|c|c|c|}
\hline \multirow{2}{*}{$\begin{array}{l}\text { WHOQOL OLD } \\
\text { Facets }\end{array}$} & \multicolumn{4}{|c|}{ Sociodemographic variables } \\
\hline & \multicolumn{2}{|c|}{ Sex } & \multicolumn{2}{|c|}{ Leisure activity } \\
\hline \multirow[t]{3}{*}{ Sensory abilities } & Male & $77.8( \pm 22.82)$ & Yes & $78.89( \pm 22.46)$ \\
\hline & Female & $69.71( \pm 22.19)$ & No & $68.91( \pm 22.18)$ \\
\hline & $p$ & 0.119 & $p$ & 0.054 \\
\hline \multirow[t]{3}{*}{ Autonomy } & Male & $62.5( \pm 23.11)$ & Yes & $62.84( \pm 23.43)$ \\
\hline & Female & $51.44( \pm 19.58)$ & No & $51.41( \pm 19.22)$ \\
\hline & $\mathrm{p}$ & $0.026^{\star}$ & $\mathrm{p}$ & $0.022^{*}$ \\
\hline \multirow[t]{3}{*}{ Past, present and future activities } & Male & 62.83( \pm 19.97$)$ & Yes & $65.54( \pm 18.79)$ \\
\hline & Female & $57.53( \pm 18.26)$ & No & $55.16( \pm 18.39)$ \\
\hline & $\mathrm{p}$ & 0.228 & $\mathrm{p}$ & $0.017^{*}$ \\
\hline \multirow[t]{3}{*}{ Social Participation } & Male & $63.16( \pm 21.54)$ & Yes & $66.39( \pm 21.92)$ \\
\hline & Female & $54.17( \pm 20.79)$ & No & $51.41( \pm 18.64)$ \\
\hline & $\mathrm{p}$ & 0.066 & $\mathrm{p}$ & $0.002^{*}$ \\
\hline \multirow[t]{3}{*}{ Death and Dying } & Male & $79.77( \pm 18.00)$ & Yes & $70.95( \pm 25.40)$ \\
\hline & Female & $63.94( \pm 24.73)$ & No & $72.5( \pm 20.74)$ \\
\hline & $\mathrm{p}$ & $0.002^{*}$ & $\mathrm{p}$ & 0.769 \\
\hline \multirow[t]{3}{*}{ Intimacy } & Male & $60.36( \pm 24.41)$ & Yes & $62.84( \pm 21.29)$ \\
\hline & Female & $56.25( \pm 18.83)$ & No & $54.22( \pm 21.53)$ \\
\hline & $\mathrm{p}$ & 0.428 & $\mathrm{p}$ & 0.082 \\
\hline
\end{tabular}

* Significance $p<0.05$

Table 5 - Multiple comparisons of interest in the sociodemographic aspect in the domains of the WHOQOL-bref of the older adults in the LSCF in Pouso Alegre and Santa Rita do Sapucaí, Minas Gerais, Brazil, 2011

\begin{tabular}{|c|c|c|c|c|}
\hline \multirow[b]{2}{*}{ WHOQOL-bref } & \multicolumn{4}{|c|}{ Sociodemographic variables } \\
\hline & \multicolumn{2}{|c|}{ Age } & Level of schooling & Average/SD/p \\
\hline \multirow[t]{4}{*}{ Physical health } & $<70$ years & $69.36( \pm 19.65)$ & No schooling & $60.81( \pm 21.53)$ \\
\hline & $70-80$ years & $65.93( \pm 23.85)$ & Primary education & $66.44( \pm 22.82)$ \\
\hline & $>80$ years & $54.53( \pm 21.13)$ & Junior High incomplete & $59.82( \pm 24.65)$ \\
\hline & $\mathrm{p}$ & $0.042^{*}$ & $p$ & 0.545 \\
\hline \multirow[t]{5}{*}{ Psychological } & $<70$ years & $67.17( \pm 16.59)$ & No schooling & $61.54( \pm 17.43)$ \\
\hline & $70-80$ years & $66.51( \pm 16.98)$ & Primary education & $68.53( \pm 17.77)$ \\
\hline & $>80$ years & $61.22( \pm 19.28)$ & Junior High incomplete & $65.63( \pm 16.63)$ \\
\hline & $\mathrm{p}$ & 0.420 & $\mathrm{p}$ & 0.267 \\
\hline & & & & continuation. \\
\hline
\end{tabular}


Table 5 - (continuation)

\begin{tabular}{|c|c|c|c|c|}
\hline \multirow[b]{2}{*}{ WHOQOL-bref } & \multicolumn{4}{|c|}{ Sociodemographic variables } \\
\hline & \multicolumn{2}{|c|}{ Age } & Level of schooling & Average/SD/p \\
\hline \multirow[t]{4}{*}{ Social Relationships } & $<70$ years & $67,67( \pm 21,83)$ & No schooling & $66.88( \pm 22.74)$ \\
\hline & $70-80$ years & $72,12( \pm 21,34)$ & Primary education & $68.97( \pm 16.20)$ \\
\hline & $>80$ years & $64,10( \pm 17,12)$ & Junior High incomplete & $68.75( \pm 23.46)$ \\
\hline & $\mathrm{p}$ & 0,363 & $\mathrm{p}$ & 0.911 \\
\hline \multirow[t]{4}{*}{ Environment } & $<70$ years & $68,00( \pm 17,94)$ & No schooling & $61.38( \pm 15.57)$ \\
\hline & $70-80$ years & $68,15( \pm 14,90)$ & Primary Education & $70.58( \pm 13.76)$ \\
\hline & $>80$ years & $62,02( \pm 12,83)$ & Junior High incomplete & $69.92( \pm 15.12)$ \\
\hline & $\mathrm{p}$ & 0,267 & $\mathrm{p}$ & $0.034^{*}$ \\
\hline
\end{tabular}

* Significance $p<0.05$

\section{Discussion}

When the older adult is first admitted to the LSCF, he or she often loses private and symbolical objects: links between the person's history and their ' $I$ '. The setting into which they are placed inhibits and distorts the reserves of private information, and a loss of intimacy of the resident occurs ${ }^{(2)}$. The activation of institutionalization causes the LSCF to take on responsibility for caring for the older adults, when their relation with their social network is interrupted, offering full support to needs, with the aim of providing a better $\mathrm{QoL}^{(13)}$.

It is necessary to make the evaluation of QoL into a care strategy for older adults, whether they are in the situation of institutionalization or not. Caring for elderly people depends on a wide range of assistance, however, in many situations the shortfall in this assistance leads the older adult to be sent to the $\operatorname{LSCF}^{(14)}$.

The evaluation of QoL through the WHOQOL-bref achieved a positive result, equal to studies of QoL of older adults in Brazilian society(15). At the same time, a study of older adults in institutions in Portugal stated that half of them believed that they had good QoL ${ }^{(16)}$. The individuals evaluated in the present study had the same levels of QoL as older adults not in institutions, which represents a favorable result.

Among the WHOQOL-bref's domains, "Social Relationships" contributed positively with the highest average, as in the studies consulted, where the authors inferred that the older adults showed themselves to be socially-adapted to their environment ${ }^{(17)}$. QoL was evaluated among older adults in institutions and in society in four cities in the State of Espírito Santo, where high scores and an association were evidenced between the domain of "Social Relationships" and the best $\mathrm{QoL}^{(18)}$. One of the important aspects for a better perception of QoL is the older adults' social coexistence, in which actions are established which promote the formation of groups for carrying out physical, leisure, cultural and work activities ${ }^{(19)}$. Probably, the stimuli are positive for the older adults' adaptation in the process of institutionalization such that the effects do not impair their social relationships and QoL as a whole. There is also evidence that the stronger the social relationships, the lower the risk of depression, and the better the mental health, among older adults ${ }^{(18)}$.

It is believed that the strategies for the development of social relationships are facilitative for the development of biological and psychological behaviors which are adaptive to stressing situations during the life of older adults in society and institutions.

It was the domain "Physical health" that most impaired QoL through the administration of the WHOQOL-bref. Studies with the QoL of older adults in institutions confirm this result in relation to the low average in the "Physical health" domain. The reduction in QoL in the older adults' "Physical health" domain may be associated with the appearance of chronic pain which also affect the maintenance of the older adult's autonomy, which may limit the performance of his or her social activities ${ }^{(20-21)}$.

It is expected that as a person ages, the probability of physical and health problems (such as musculoskeletal problems and impairment of activities of daily living due to little disposition or energy, or fatigue) involving the appearance of pain increases, and that institutionalization is related to greater physical dependence ${ }^{(20)}$.

Various studies have confirmed that older men have higher scores than women in all the domains of QoL. This may be confirmed by the influence which questions 
of gender represent in QoL, with aging being considered more negatively by women, as impairing the domains of QoL. It is important to emphasize that the profile of the older adults in the LSCF showed a balance between the sexes, which differs from the literature. This may be explained by the equality between the spaces offered in the LSCF studied. The higher percentage of older women institutionalized in Brazil is well-known, with longevity, widowhood, and low levels of education and income all being contributing factors to institutionalization ${ }^{(22)}$.

The older adults who undertook physical exercise were associated with the physical, psychological and environmental domains and in the WHOQOL-bref general scale. These findings corroborate the results of a systematic review which investigated physical activity's impact on older adults' quality of life, identifying that physical exercise collaborates in the improvement of older adults' QoL, as it helps them to maintain vigor and energy for daily activities and a reduction of physical disabilities, thus allowing improvement in autonomy(23). Regular physical activity among older adults in LSCF has beneficial effects on QoL, as shown by a randomized study in Turkey in 2010, which evidenced an improvement in balance, a reduction in the risk of falls, improvement in the muscular structure (principally in the lower limbs), and improvement in breathing, which allowed more autonomy in activities of daily living among older adults in $\operatorname{LSCF}^{(24)}$.

Leisure activities have high scores in the WHOQOL OLD module's facets autonomy and past, present and future activities. Leisure activities and coexistence in groups contribute satisfactorily to the older adult's biopsychosocial balance(25). Older adults stress the importance of social and leisure activities for QoL, as these develop participation in groups through trips, fishing, and dances, which are essential activities for maintaining QoL, as they keep them in contact with other people and environments, developing a perception of being a member of society ${ }^{(26)}$. Activities of leisure and recreation are inserted in the domain "environment", which had the second-highest score in the WHOQOLbref in this research. This result confirms the influence of leisure activities on older adults' QoL.

A Canadian study emphasizes the influence of older adults' values, beliefs, policies and attitudes on the environment. These perceptions must be promoted in the daily life of older adults in LSCF. The professionals in the institutions have a fundamental role in the promotion of the characteristics of an ideal climate. The study also refers to the importance of humanization in the LSCF, seeking to respect the older adults' opinions(27).
Only the physical domain had significance when age ranges among the older adults were compared. It was evidenced that the oldest among the older adults had the lowest QoL index. This data was confirmed by a study undertaken in four LSCF in Portugal, where the authors observed that the QoL index varies according to the age group, with a decline in QoL being evident in line with the advance in age ${ }^{(16)}$.

It was evidenced that among the WHOQOL-bref domains only "environment" had significance with the levels of schooling. It was evidenced that there is a difference in QoL scores among the older adults with no schooling and those with primary education; older adults without schooling had, on average, lower scores in relation to the environment.

The physical environment in which the older adult resides provides the dependence or not of the individual, this depending directly on the stimulus received ${ }^{6}$ ). Older adults who live in less secure environments are less likely to go out alone and, therefore, are more susceptible to isolation and depression, as well as having mobility problems and a worse physical state, which influence their quality of life(28). The low level of schooling among the older adults is a reality in developing countries. This situation directly impairs the QoL of these people regarding the understanding and acceptance of advice, as well as having various limitations on visual and auditory acuity. It falls to the professionals caring for the older adults to use accessible, easily-understood language, for the care to be successful.

The self-evaluation of QoL in the WHOQOL-OLD module made it possible to ascertain that the results were similar to other studies with institutionalized older adults in Blumenau (Santa Catarina, Brazil). However, the WHOQOL-OLD module with older adults in LSCF in Bahía obtained different results, with a lower QoL index ${ }^{(27)}$.

The facet "Sensory ability" had the most significant average in this study, as in other research with older adults in institutions. This facet is represented by the senses: the loss of hearing, vision, taste, smell or touch impair daily life, the capacity to participate in activities, and the capacity to interact with other people, making the older adult dependent on care. The older population's QoL is involved with the maintenance of functional ability or autonomy and the older adult who manifests impairment of the senses may suffer reduction in functional ability and, consequently, impairment of quality of life ${ }^{(28)}$. 
The facet with the lowest score was Autonomy, which is related to the ability to take decisions and to functional independence - that is, the ability to do something on one's own ${ }^{(13)}$. The older adult population's QoL is involved not only in maintaining functional ability but also in the loss of autonomy, which presents impairment of the senses, which can trigger reduction in functional ability and, consequently, impairment of QoL (28).

These findings contribute to helping managers and care professionals in the care of older adults in LSCF, evidencing the importance of the stimulating of social relationships, mental and physical exercise and maintaining these older adults' QoL.

\section{Limitations of this study}

This study's limitations are related to the purposive selection of the sample, which is not the gold standard for generalization of information. The variables and the older adults' level of depression and income were not associated with the QoL. The literature consulted shows a strong relationship between these variables and the impairment of QoL among older adults. The efforts made for these limitations not to compromise the development and outcome of this study stand out.

\section{Conclusions}

From these results it may be concluded that the older adults' QoL in the two LSCF in Pouso Alegre and Santa Rita do Sapucaí, Minas Gerais, evaluated with the generic instrument WHOQOL-bref and the specific instrument WHOQOL-OLD permitted, in general, the showing of positive results, superior to other older adults in institutions and similar to the QoL of older adults in the community.

The self-evaluation of generic QoL with the WHOQOLbref evidenced that the older adults participating in this study were satisfied with their QoL. The Social Relationships domain stood out from the others. The domains of the WHOQOL-bref had a correlation with the variables: age, sex, schooling, and undertaking of physical activity.

The module specifically for older adults' QoL - the WHOQOL-OLD - showed positive results, with higher scores in the facet Sensory abilities. Its facets had correlations with the variables: sex and undertaking leisure activities.

Through these results it is possible to show that younger older adults, with higher levels of schooling, who regularly undertake physical and leisure activities, have, on average, better perceptions of QoL.

This construct has strong implications for professional practice in health, with the aim of supporting quality care. Studies of this should be encouraged to use probabilistic sampling, observational cohorts, or intervention in other scenarios, such that the QoL of older adults in institutions may be explored.

The results suggest the training of those involved with older adults in institutions, so that they may develop strategies relevant to provide encouragement in the adaptation, adjustment and maintenance of QoL in general.

\section{References}

1. Ferreira DCO, Yoshitmoe AY. Prevalence and features of falls of institutionalized elders. Rev Bras Enferm. novdez 2010;63(6):991-7.[português] Disponível: http:// www.scielo.br/pdf/reben/v63n6/19.pdf

2. Del Duca GF, Silva SG, Thumé E, Santos IS, Hallal PC. Predictive factors for institutionalization of the elderly: a case-control. Rev Saúde Pública [periódico na Internet]. 2012,[acesso $8 \mathrm{dez} 2010] ; 46(1): 147-53$. [inglês]. Disponível em: http://www.ncbi.nlm.nih.gov/ pubmed/22249756

3. IBGE - Instituto Brasileiro de Geografia e Estática [Internet]. Estimativa das populações residentes 2009. [acesso 7 jan 2010]. Disponível em www.ibge.gov.br/.../ populacao/estimativa2009/POP2009_DOU.pdf.

4. Camarano AA. Características das instituições de longa permanência para idosos - região Sul. Brasil: IPEA, Presidência da República, 2008. [acesso 6 julho 2012]; CNA. Disponível: http://www.ipea.gov.br/sites/000/2/ pdf_release/08_07_11_IdososSul_Ipea_Ipardes.pdf 5. Creutzberg M, Gonçalves LHT, Sobottka EA, Ojeda BS. Long-Term Care Institutions for Elders and the health system. Rev. Latino-Am. Enfermagem. nov-dez 2007;15(6):1144-9.[ingles] Disponível em: http:// www.scielo.br/pdf/rlae/v15n6/13.pdf

6. The Whoqol Group. The World Health Organization Quality of Life Assesssment (WHOQOL): position paper from the World Health Organization. Soc Sci Med. 1995;41(10):1403-9.

7. Fleck MP, Louzada S, Xavier M, Chachamovich E, Vieira G, Santos L, Pinzon V. Application of the portuguese version of the instrument for the assessment of the quality of life of the World Health Organization (WHOQOL-100). Rev Saúde Pública.1999;33(2):198-205. 
8. Fleck MP, Chachamovich E, Trentini C. Development and validation of the Portuguese version of the WHOQOLOLD module. Rev Saúde Pública. [periódico na Internet]. 2006; [acesso 5 julho 2012]; 40(5):785-91. [inglês] Disponível: http://www.scielo.br/pdf/rsp/v40n5/07.pdf.

9. Tajvar M, Arab M, Montazeri A. Determinants of health-related quality of life in elderly in Tehran, Iran. BMC Public Health. 2008;8:323. DOI: 10.1186/14712458-8-323

10. Perlini NMOG, Leite MT, Furini AC. Looking for a nursing home for an elderly person: reasons appointed by relatives. Rev ESC Enferm USP. [periódico na Internet]. 2007; [acesso 5 julho 2012]; 41(2):22936. [português]. Disponível: http://dx.doi.org/10.1590/ S0080-62342007000200008.

11. Lucas-Carrasco R, Laidlaw K, Power MJ. Suitability of the WHOQOL-BREF and WHOQOL-OLD for Spanish older adults. Aging Ment Health. 2011 Jul 1;15(5):595-604. DOI: $10.1080 / 13607863.2010 .548054$

12. Fleck Marcelo PA, Chachamovich E, Trentini CM. WHOQOL-OLD Project: method and focus group results in Brazil. Rev Saúde Pública. [periódico na Internet]. 2003; [acesso 5 julho 2012];37(6):793-9. [inglês] Disponivel em: http://www.scielo.br/pdf/rsp/v37n6/ en_18024

13. Bessa MEP, Silva MJ, Borges CL, Moraes GLA, Freitas CASLima. Elderly residents in long-term institutions: the use of spaces in the construction of everyday life. Acta Paul. Enferm. [periódico na Internet]. 2012; [acesso 5 julho 2012];25(2):177-82. [Inglês].. Disponível: http:// www.scielo.br/pdf/ape/v25n2/en_a04v25n2.pdf.

14. Paskulin LMG, Vianna LAC, Molzahn AE. Factors associated with quality of life of Brazilian older adults. Intern Nurs Rev. 2009;56(1):109-15. DOI: 10.1111/j.1466-7657.2008.00671.x

15. Paskulin LMG, Vianna LAC. Sociodemographic profile and self-referred health conditions of the elderly in a city of Southern Brazil. Rev Saúde Pública. [periódico na Internet].2007; [acesso 5 julho 2012]; 41(5):75768 [português] http://dx.doi.org/10.1590/S003489102007000500010

16. Almeida AJ, Pereira S, Rodrigues V, Manuel CP. The quality of life of aged people living in homes for the aged. Rev. Latino-Am. Enfermagem . dez 2008;16(6):102531. [inglês]

17. Carneiro RS, Falcone E, Clark C, Prette ZD, Prette AD. Quality of life, social support and depression of the elderly: relation with social abilities. Psicol Reflexão e Crítica. 2007;20(2):229-37.[português].

18. Oliveira ERA, Gomes MJ, Paiva KM. Institutionalization and quality of life in elderly at metropolitan region in Vitória - ES, Brazil - ES. Esc Anna Nery. [periódico na Internet]. jul/set 2011; [acesso 5 julho 2012]; 15(3). Disponível em: http://dx.doi.org/10.1590/S141481452011000300011.

19. Murakami L, Scattolin F. Evaluation of functional independence and quality of life in institutionalized elderly. Rev Med Hered. [periódico na Internet]. 2010;21.. [acesso 5 julho 2012]; [português] Disponivel: http://www.scielo.org.pe/scielo.php?script=sci_ arttext\&pid=S1018-130X2010000100004\&Ing=es\&nrm =iso

20. Cunha LL, Mayrink WC. Influence of chronic pain in the quality of life of the elderly. Rev Dor. 2011;12(2):1204.

21. Lung FW, Huang YL, Shu BC, Lee FY. Parenteral rearing style, premorbid personality, mental health and quality of life in chronic regional pain: A causal analysis. Compr Psychiatry 2004:45(3):206-12. DOI: http:// dx.doi.org/10.1016/j

22. Alencar NA, Aragão JC, Bezerra FMA, Dantas EHM. Avaliação da qualidade de vida em idosas residentes em ambientes urbano e rural. Rev Bras Geriatr Gerontol. [periódico na Internet]. 2010; [acesso 5 julho 2012];13(1):103-109. Disponível em: http://revista. unati.uerj.br/scielo.php?script=sci_arttext\&pid=S180998232010000100011\&lng=pt.

23. Oliveira ACO, Núcia MD, Arantes PMM, Alencar MA. Qualidade de vida em idosos que praticam atividade física: uma revisão sistemática. Rev Bras Geriatr Gerontol. ago 2010;13(2):301-12.

24. Cakar E, Dincer U, Kiralp MZ, Cakar DB, Durmus O, Kilac H, Soydan FC, Sevinc S, Alper C. Jumping combined exercise programs reduce fall risk and improve balance and life quality of elderly people who live in a long-term care facility. Eur J Phys Rehabil Med. [periódico na Internet]. 2010 Mar; [acesso 5 julho 2012]; 46(1):59-67. Disponivel: http://www.ncbi.nlm. nih.gov/pubmed/20332728

25. Valadares ALR; Carvalho ED; Costa-Paiva LH; Morais SS; Pinto-Neto AM. - Association between different types of physical activities and quality of life in women aged 60 years or over. Rev Assoc Med Bras. [periódico na Internet]. 2011 JulAug;[acesso 5 julho 2012]; 57(4):450-5. Disponível em: $\quad$ http://www.scielo.br/scielo.php?script=sci_ arttext\&pid=S0104-42302011000400021\&lng=en\&nrm =iso\&tlng=en DOI: http://dx.doi.org/10.1590/S010442302011000400021. 
26. Tahan J, Carvalho ACD. Reflections of aged participating in the health promotion groups concerning the ageing and the quality of life. Saude Soc. [periódico na Internet]. 2010; [acesso 5 jun 2012];19(4):878-88. [português]. Disponível em: http://dx.doi.org/10.1590. 27. Robichaud L, Durand PJ, Bédard R, Ouellet JP. Quality of life indicators in long term care: Opinions of elderly residents and their families. Can J Occup Ther. 2006 Oct;73(4):245-51.Doi:10.2182/cjot.06.003. Disponível:http://www.caot.ca/CJOT_pdfs/CJOT73/ robichaud2.p

28. Pereira RJ, Cotta RMM, Franceschini SCC, Ribeiro $\mathrm{RCL}$, Sampaio RF, Priore SE, Cecon PR. Contribution of the physical, social, psychological and environmental domains to overall quality of life of the elderly. Rev Psiquiatr Rio Gd Sul [periódico na Internet]. 2006; [acesso 5 julho 2012];28(1):27-38. [inglês]. Disponível em: $\quad$ http://www.scielo.br/scielo.php?script=sci_ arttext\&pid=S0101-81082006000100005\&lng=en\&nrm $=$ iso\&tlng $=p t$ 